\title{
ASSESMENT OF PM10 POLLUTION EPISODES IN A CERAMIC CLUSTER (NE SPAIN): PROPOSAL OF A NEW QUALITY INDEX FOR PM10, As, Cd, Ni AND Pb
}

\author{
Vicente A. B. ${ }^{(1)}$, Sanfeliu T. ${ }^{(1)}$, Jordan M.M. ${ }^{(2)}$ \\ (1) Agricultural and Environmental Sciences Department. Jaume I University. \\ Campus Riu Sec s/n 12071 Castellón, Spain. E-mail: avicente@camn.uji.es. \\ (2) Agrochemistry and Environment Department. Miguel Hernández University \\ Avda. de la Universidad s/n. 03202 Elche (Alicante), Spain.
}

\begin{abstract}
Environmental pollution control is one of the most important goals in pollution risk assessment today. In this sense, modern and precise tools that allow scientists to evaluate, quantify and predict air pollution are of particular interest. Monitoring atmospheric particulate matter is a challenge faced by the European Union. Specific rules on this subject are being developed (Directive 2004/107/EC, Directive 2008/50/EC) in order to reduce the potential adverse effects on human health caused by air pollution. Air pollution has two sources: natural and anthropogenic. Contributions from natural sources can be assessed but cannot be controlled, while emissions from anthropogenic sources can be controlled; monitoring to reduce this latter type of pollution should therefore be carried out. In this paper, we describe an air quality evaluation in terms of levels of atmospheric particles (PM10), as outlined by European Union legislation, carried out in an industrialised Spanish coastal area over a five-year period with the purpose of comparing these values with those of other areas in the Mediterranean Basin with different weather conditions from North of Europe. The study area is in the province of Castellón. This province is a strategic area in the frame work of European Union (EU) pollution control. Approximately $80 \%$ of European ceramic tiles and ceramic frit manufacturers are concentrated in two areas, forming the so-called "ceramics clusters"; ones in Modena (Italy) and the other in Castellón. In this kind of areas, there are a lot of air pollutants from this industry then it is difficult to fulfill de
\end{abstract}


European limits of PM10 so it is necessary to control the air quality in them. The seasonal differences in the number of days in which pollutant level limits were exceeded were evaluated and the sources of contamination were identified. Air quality indexes for each pollutant have been established to determine easily and clearly the quality of air breathed. Furthermore, in accordance with Directive 2008/50/EC, an Air Quality Plan is proposed to protect human health, and the environment as a whole, in the study area. General and specific corrective measures of main emission sources are provided. A strategy for air pollution management is thus presented.

Keywords: Air Pollution. Monitoring. PM10. As. Cd. Ni. Pb. Ceramic Cluster. Air Quality Plan. Castellón.

\section{INTRODUCTION}

Recently, advancement in economic conditions has been able to nourish the development of environmental regulations and investments in environmental management and pollution control (Li et al., 2004). Monitoring atmospheric particulate matter is a challenge faced by the European Union. Specific rules on this subject (Directive 2004/107/EC, Directive 2008/50/EC) are being developed to reduce the potential adverse effects on human health caused by air pollution. Other adverse effects of this kind of pollution include reduced visibility and an increase in problems affecting the climate (Kelessis, 2001), such as global warming, environmental acidification, photochemical smog, and ozone layer depletion (Kantarci et al., 2001; Mc Michael et al., 2006; Sivakumar, 2007 ). The European Parliament has outlined the need to reduce atmospheric pollution to levels that minimise harmful effects on both human health, with particular attention paid to sensitive populations, and the environment as a whole. 
Its objectives are to improve the monitoring and assessment of air quality, including pollutant emissions and to provide information to the public.

To ensure that the information collected on air pollution is sufficiently representative and comparable across the European Union, it is important that standardised measurement techniques and common criteria for the number and location of measuring stations are used for the assessment of ambient air quality. At the same time, air quality plans should be developed for zones or agglomerations where pollutant concentrations in the ambient air exceed target or limit values, in addition to any temporary margins of tolerance, where applicable. Then environmental technology may need to be introduced to reach these target values.

In this study, air quality evaluation in terms of the levels of the atmospheric particles, PM10 (particulate matter $<10 \mu \mathrm{m}$ ) was performed in a Spanish coastal area (the municipality of Vila-real) for five years (2001-2005) with the purpose of comparing these values with those of other areas in the Mediterranean Basin with different weather conditions from North of Europe. This pollutant was analysed because it may indicate a much higher health risk despite its low representation when compared to gas pollutants. This pollutant enters the body exclusively through the respiratory system. Its effects depend on whether or not it enters the respiratory tract, with the degree of penetration depending on particle size (Foster, 1999). Recent studies have shown a positive correlation between high concentrations of particulate matter and deterioration in human health (Kappos et al, 2004; Neuberger et al., 2004; Le Tertre et al., 2005; Wilson et al., 2005). The underlying biological causes of the health effects of fine particles exposure 
are not clear, thus the investigation of their physical and chemical characteristics is important to elucidate particles toxicity (Marcazzan et al., 2001).

In addition, particles can have a toxic effect. They may be inherently toxic due to chemical and/or physical characteristics, they may interfere with one or more of the mechanisms that usually clear the respiratory tract, or they may act as conductor to toxic substance absorption (López et al., 2005). For example, particles can act as a driver of heavy metals. Generally, fine particulate matter carries the burden of heavy toxic metals more than coarse fractions (Shah et al., 2006). With this in mind, the concentrations of $\mathrm{As}, \mathrm{Cd}, \mathrm{Ni}$ and $\mathrm{Pb}$ detected in $\mathrm{PM} 10$ were determined according to European regulations (Directive 2004/107/EC, Directive 2008/50/EC). Chemical elements measurements can also help to tracer specific emission patterns. Thus, the knowledge of the chemical composition of particle matter can be used to evaluate the impacts of the various pollution sources on air quality (Mazzei et al., 2008).

Furthermore, in accordance with Directive 2008/50/EC, an Air Quality Plan has been outlined in order to protect human health and the environment as a whole in the study area. Air Quality Indexes for each pollutant have been established to easily and clearly understand the quality of air breathed in the study area. The Air Quality Index is scale of colours designed to help understand the impact of air quality on health. It is a protection tool used to make decisions to reduce short-term exposure to air pollution by adjusting activity levels during high levels of air pollution. 


\section{The study area}

The area analysed in this study is located in the south-west part of the municipality of Vila-real. This industrial city is situated in the eastern part of the province of Castellón (Spain), $46 \mathrm{~m}$ above sea level in the Plana Baixa subdivision. This province is a strategic area in the frame work of European Union (EU) pollution control. Approximately $80 \%$ of European ceramic tiles and ceramic frit manufacturers are concentrated in two areas, forming the so-called "ceramics clusters"; ones in Modena (Italy) and the other in Castellón. Based in recent studies (Querol et al., 2008) and the internet data from regional authorities derived from air quality networks in these areas suggest that PM and metals are the two most important parameters with regard to EU legal requirements for air quality standards (Minguillón et al., 2007).

The type of climate in the study area is Mediterranean, a variety of subtropical climate characterized by wet and mild winters, dry and warm summers, and a temperature variation of $13.5^{\circ} \mathrm{C}$. Rainfall is abundant in spring and autumn, coinciding with the dominance of western winds. The rains generally do not exceed $400 \mathrm{~mm}$ annually. Summer is dominated by the Azores anticyclone (Vicente et al., 2011).

This area has a complex Mediterranean atmospheric environment, with low rainfall, soil with poor vegetation coverage and frequent high particulate air-mass intrusions from the Sahara (Rodríguez et al., 2002). A system of local breezes is also present in the study area due to geographical characteristics and the proximity to the sea. These periodic land-sea winds, which have been extensively studied by several authors (Martín et al., 1991; Boix et al., 1995; Millán et al., 2001; Sanfeliu et al., 2002), govern the microclimate in this area, resulting in an overall effect of smoothing the temperatures 
(Posgosyan, 1965). Due to this system of breezes, the concentration of pollutants may be affected by emission sources located outside the Vila-real on a daily basis (Fig. 1).

The planning of effective strategies for the abatement of atmospheric PM concentrations requires the evaluation of source contributions to the PM levels (Bernardorni et al., 2011). The origin of PM10 in this area is both natural and anthropogenic. The former is due to the resuspension of mineral materials from the surrounding mountains with poor vegetation coverage and the long-range transport of materials from North Africa (Rodríguez et al. 2001, Pérez et al. 2006). These dust intrusions from North Africa influence ambient PM10 levels in the study area at around $2 \mu / \mathrm{m}^{3}$ on an annual basis (Minguillón et al, 2009). Contributions from natural sources can be assessed but not controlled.

Anthropogenic pollution sources originate from automobile traffic (mobile sources) and industrial activity (fixed sources). The main industrial activity in the study area is based on producing ceramic tile (Vicente et al. 2007).. This industrial sector has two types of factories, one for the manufacture of tiles and the other to supply raw materials. The raw materials of the tile body consist mainly of clay from sources such as opencast quarries within the ceramic cluster area (Jordán et al., 2009; Sanfeliu et al., 2009). The raw materials for decoration involve manufacture frits, enamels, and colour (Jordán et al., 2006). In the manufacture of ceramic tile, channelled and diffuse emissions from the production processes and the storage, handling and transport of raw materials all increase the concentration of particles in the air (Sanfeliu et al., 2002). However, particle emissions from the manufacture of pigments, frits and enamels probably have a greater impact on the levels of heavy metals than on particle mass. (Minguillón et al., 
2007). An additional important factor is that a power station, a refinery and several chemical industries are located at east of the study area (Boix et al., 2001). These industries together contribute to environmental pollution in the area. Finally, relevant sources of secondary PM in the area include precursor emissions of the volatile organic compounds (VOC's), $\mathrm{NOx}$ and $\mathrm{SO}_{2}$ from high temperature ceramic processes, power generation, petrochemical processes and biomass combustion (Minguillón et al., 2007).

In the case of chemicals pollutants in PM10, concentration levels of arsenic are associated with fossil fuel combustion (traffic, power station, refinery and chemical industries; Ghio and Samet 1999) Nevertheless, the main source of Arsenic contribution in the study area is related to industrial processes based on nonmetallic materials, such as the ceramic industry. This element is found as an impurity in boracic compounds (colemanite and hydroboracite), used in the formulation of frits and enamels, which means a possible arsenic origin, from its volatilization and/or vaporization during the firing and fusion processes (Pallarés et al., 2007). Nickel is found as a trace element in petrol, and therefore its release into the atmosphere is related mainly to the combustion of fossil fuels (coal and fuel oil) in electricity and heat production and traffic emissions (Pacyna et al. 1984; Ghio and Samet 1999). Nickel oxides are also widely used as components of the pigments used in the ceramics industry. The concentration levels of cadmium in ambient air are associated with industrial processes in the manufacturing of frits and enamel. Emissions of cadmium are also produced in the processes of the power station (Boix et al. 2001). The most important emission of lead is traffic. Petrol additives contain lead (Parekh et al. 2002), which after combustion is released into the atmosphere as organic lead (lead bromide and lead 
chlorinebromide) (Pacyna 1998). With the introduction of new international laws, the use of lead in petrol has been banned, and this contribution is now minimal, its use reduced to obsolete means of transportation. In the ceramics industry, lead oxides are also used extensively as a component of pigments. Relationships between the emissions from this sector to air ambient levels of lead in close urban areas have been identified (Sanfeliu et al. 2002; Gómez et al. 2005).

Bearing in mind that these emissions are from anthropogenic sources and can thus be controlled, monitoring should be carried out to reduce pollution.

\section{METHODOLOGY}

\section{Sampling conditions}

The sampling station was set up in the southwest part of the city (UTM: X 746,543 Y $4,424,906)$ in accordance with the implementation guidelines of European Council Directive 2008/50/EC. In order to avoid measuring microclimates, the sampling station was situated $3 \mathrm{~m}$ above ground level on a special metallic platform in an open area covering at least $500 \mathrm{~m}^{2}$. There were no local emission sources nearby so that a distortion of the samples due to the influence of smoke plumes from specific pollutants was avoided.

A PM10 medium volume sampler model IND-LVS3 manufactured by Kleinfiltergerät was used. This device is considered as a reference according to European regulations (Council Directive 2008/50/EC; EN 12341:1999), for the sampling of PM10 particles. The technology used in the equipment consists of blowing air through an inlet with a 
vacuum pump. The particulate matter was blown in through the opening circumference between the frame and the round cover mounted on top. Within the sampler inlet the airflow was accelerated by eight impactor nozzles and then directed toward the impacting surface. Particles were trapped on a permeable support consisting of a $47 \mathrm{~mm}$ diameter filter. The device contains a temperature sensor with a radiation protector that eliminates deviations in the reading caused by solar radiation in addition to a pressure sensor. The sampling flow volume was $2.3 \mathrm{~m}^{3} / \mathrm{h}$ during $24 \mathrm{~h}$ periods. A total of 887 PM10 samples were collected in filters from 2001 to 2005 . The filters used were quartz fiber according to EN 12341:1999. They made of from $\mathrm{Si} \mathrm{O}_{2}$ pure base and are totally free of additives. These filters allow an efficiency of separation greater than $99.5 \%$.

\section{Gravimetric analysis}

Particle concentration levels were determined gravimetrically. This method consists of weighing the empty filter first and then again with the sample. In order to weigh the filter correctly, it must be conditioned for at least $48 \mathrm{~h}$ in a special chamber. The conditions inside the chamber are $50 \%$ relative humidity at $20^{\circ} \mathrm{C}$ in accordance with the normative EN 12341:1999. Filters were weighed on an analytical balance with a precision of $0.1 \mathrm{mg}$. The PM concentration levels were determined based on the sample quantities obtained and the volume of air pumped.

\section{Chemical analysis}

The levels of $\mathrm{As}, \mathrm{Cd}, \mathrm{Ni}$ and $\mathrm{Pb}$ in the PM10 samples were determined by inductively coupled plasma mass spectrometry (ICP-MS). The equipment used was a Agilent model 7500CX that included a quadrupole, a collision cell and an integrated autosampler. The equipment was installed in a chamber with a clean air filter unit and an independent air 
conditioning system. This instrumental technique allows the $\mathrm{As}, \mathrm{Cd}, \mathrm{Ni}$ and $\mathrm{Pb}$ levels to be rapidly identified after dissolution of the sample. Dissolution was achieved by acid digestion in hermetic Teflon recipients. This methodology has been used by many authors (Kubilay et al., 1995; Querol et al., 2000).

In order to detect any possible traces of contamination-causing $\mathrm{As}, \mathrm{Cd}, \mathrm{Ni}$ or $\mathrm{Pb}$ contained in the reagents and quartz filter fibres, digestions with only reagents (blank reagents) and filters without a sample (blank filters) were performed. The SRM 1648 "urban particulate matter" pattern was used to validate the results. This pattern consists of particulate matter of anthropogenic origin collected in an industrialised urban atmosphere and was an adequate standard of reference for this study.

\section{RESULTS AND DISCUSSION}

\section{PM10}

Table 1 shows the assessment of PM10 according to the limit values established by current legislation (European Council Directive 2008/50/EC). The highest numbers of exceedences of daily limit values were detected in 2005. In the same year, the highest annual average within the five-year period studied was obtained. The values obtained in 2001 are close to those of 2005. From 2001 to 2004, a progressive decrease in the concentration levels of PM10 occurred, but this trend did not continue in 2005.

Assessment included only the days sampled each year, not all $365 \mathrm{~d}$ of the year, as outlined in Directive 2008/50/EC. The 35 d in which the legal limit value was exceeded correspond to $9.6 \%$ of the full year. Table 2 shows the percentages of days with exceeded levels in the five-year period. Based on this reassessment, a decrease in these percentage values can be observed from 2001 to 2004, followed by an increase in 2005 . 
However, the percentages of exceedances of daily limit value obtained during five years of study are higher than the percentage limit. Consequently, the limit values recommended by EU legislation for the protection of human health and ecosystems have not been complied with in the study area.

The seasonal evolution of the number of exceedances the proposed limit value of PM10 could supply valuable information about the potential origin of particles. These seasonal variations are dominated by changes in meteorological conditions (Chang et al., 2008). In this case, a tri-modal trend is observed, with peaks in spring, summer and winter (Fig. 2). The same pattern was detected by Alastuey et al. (2000) in Onda, a town close to Vila-real $(15 \mathrm{Km})$. PM10 levels increase during the months with high temperatures (from June to August) due to a decrease in precipitation. This causes a reduction in the cleansing effect on the atmosphere (Bergametti et al. 1989) and consequently a greater contaminant concentration in the ambient air. The high temperatures during these months lead to increased dryness of the terrain, which favours the resuspension of clayloam substrate in the area (Gómez et al., 2005). At the same time, the mixing layer, or lower part of the troposphere where the pollutants are free to move through the turbulence generated in the lower layers of the atmosphere, increases its thickness and facilitates the mixing of air masses from the north of Africa in the low layers (Kubilay et al., 1995). Intrusion episodes of long-distance material occur, leading to an increase in the concentration of PM10. The days in which material intrusions from long transport are detected are presented in Table 3.

During the winter months, temperature inversions are generated. This phenomenon occurs on clear nights when the soil loses the heat acquired by radiation and low-lying 
air layers are cooled faster than the upper layers of air. (Wallace et al., 2010). When pollutants are emitted under temperature inversion conditions, they accumulate in the layers of the troposphere close to the ground. This phenomenon causes transport through these layers to occur too slowly, producing an increased concentration of pollutants (Monn et al., 1995). This accumulation of pollutants is also found in Milan due to persistent thermal inversions (Marcazzan et al, 2001).

During the autumn season, the lowest values of the study were detected. This was due to atmospheric instability, the tendency of the atmosphere to resist or enhance vertical motion or, alternatively, to suppress or augment existing turbulence (Zoras et al., 2006). As global weather conditions change, the input frequency of air masses from North Africa is reduced (the mixed layer decreases), rainfall increases, and there is a greater cleansing effect in the atmosphere (Querol et al., 2002).

\section{Quality Index for PM10}

Table 4 presents the Daily Quality Index Criteria for PM10 reflecting the daily limit value specified in the legislation. Figure 3 shows the percentage of days in each range. Green and blue colours associated with good air quality and yellow and red colours corresponding to poor air quality are distributed equally. It may be clearly observed that the days in which the limit value of PM10 is exceeded and the days in which this limit is not exceeded are equal in number. According to this criterion, 2004 had the best air quality, while 2005 had the worst.

\section{As, Cd, Ni and Pb in PM10}


Table 5 shows the assessment of $\mathrm{As}, \mathrm{Cd}, \mathrm{Ni}$ and $\mathrm{Pb}$ levels in PM10 according to the limit values established by current legislation (European Council 1999/30/EC for Pb and Directive 2008/50/EC for As, Cd, and Ni). The annual average values for lead, cadmium and nickel were below the recommended limit during the five-year study period. Air pollution due to these pollutants was not detected in the study area. For lead and cadmium, the annual average values decreased during the study period. An improvement in air quality in terms of these pollutants was observed. At the same time, the annual average values for nickel dropped from 2001 to 2003 and then increased until 2005. Although the annual average values for arsenic decreased during the fiveyear study period, the recommended limit value according to current legislation was not met in 2001, 2002 or 2003. An improvement was observed starting in 2004, when the limit value was first met. Being in mind that the main sources of Arsenic in the study area is from raw materials used in ceramic industry; this kind of industry changed their raw materials to others more cleanly during study period. Thus there has been an improvement in air quality concerning this pollutant.

The distribution of the number of days per month with exceeded limit values for lead $\left(500 \mathrm{ng} / \mathrm{m}^{3}\right)$, arsenic $\left(6 \mathrm{ng} / \mathrm{m}^{3}\right)$ and cadmium $\left(5 \mathrm{ng} / \mathrm{m}^{3}\right)$ is continuous and no trend may be observed (Figs. 4, 5 and 6). In the case of nickel (20 ng/m $\mathrm{m}^{3}$, Fig. 7), limit value exceedences were very infrequent, taking place only from May to August.

\section{Quality Index for $\mathrm{As}, \mathrm{Cd}, \mathrm{Ni}$ and Pb in PM10}

Table 6 shows the Quality Index Criteria for $\mathrm{As}, \mathrm{Cd}, \mathrm{Ni}$ and $\mathrm{Pb}$ in accordance with the limit values set by the legislation. Figures 8 to 11 show the percentages of days in each range of the quality index criteria for each pollutant. 
In the case of lead (Fig.8), the predominant colours were green and blue, corresponding to a low level of contamination during the study period. However, it should be noted that during 2001, 2002 and 2003 a small percentage of yellow and red for poor air quality appeared. This improved in 2004 and 2005.

From 2001 to 2003, the predominant colours for arsenic were yellow and red due to the pollution from this element being very high (Fig. 9). Green and blue colours during 2004 and 2005 were observed, indicating a significant improvement in air quality.

Cadmium (Fig. 10) and nickel (Fig.11) levels did not produce yellow or red colours in the figure, reflecting good air quality with regard to these two pollutants from 2001 to 2005.

\section{Air Quality Plan}

In view of the results from the study area, it is necessary to implement an Air Quality Plan to improve the control of air quality, thus promoting sustainable development, to ensuring a future with quality parameters within limit values, guaranteeing the welfare of the population and preserving natural ecosystems and material goods.

The origin of pollutants in this area is both natural and anthropogenic (see Introduction). Contributions from natural sources can be assessed but not controlled; emissions from anthropogenic sources, meanwhile, are controllable and should be monitored and reduced. With an Air Quality Plan, the specific actions at different levels of intervention can affect different anthropogenic emission sources and be tailored to each pollutant. 
These actions may be general or specific to each subgroup of emission sources. In the study area, the main pollutants are automobile traffic and the ceramic industry. Therefore, the measures taken in the Air Quality Plan specific to Vila-real should, for the main part, adapt to these emission sources.

\section{General corrective measures}

These measures are aimed at all populations in general. The main objective is to educate the public on problems of air quality. The following are proposed measures:

- Promote campaigns to raise public awareness.

- Inform the public of the advantages of public transport and the environmental risks and costs of private vehicles.

- Inform the public of emissions and the associated risks to human health.

- Promote renewable energy systems (e.g. hot water heating derived from solar energy).

- Plant trees that cause a sink effect on greenhouse gases. These vegetation fences must be properly oriented to the direction of prevalent daytime winds.

- Carry out management with government grants and subsidies that involve all sectors of population (citizens and local public or private entities).

\section{Corrective measures for automobile traffic}

\section{General:}

- Restrict private car use and encourage the use of public transport services.

- Modify office or work activity hours. 
- Report on atmospheric pollution and identify the measures that affect the mobility of citizens.

Specific:

- Control vehicle emissions.

- Establish agreements with public transport and car park companies.

- Maintain strict control of parking prohibitions and certain driving infractions.

- Reduce the speed limit on certain roadways.

Territorial:

- Create a detour for vehicles around polluted areas.

- Implement plans to change the settings of traffic lights to modify the access to and exit from contaminated areas by motor vehicles.

- Redistribute public transport lines.

- Subsidize public transport services to encourage its use.

- Increase pedestrian areas and encourage walking inside urban areas.

\section{Corrective measures in the industry}

\section{General:}

- Restrict the use of certain fuels and eliminate polluting fuels.

- Promote renewable energy.

- Modify the activity of certain production processes to make cleaner processes more viable.

- Establish protocols and agreements with industries that are potentially polluting for appropriate corrective action. 
Introduce fiscal tools that both encumber the pollution caused by companies such as those in the energy industry and promote a system that will reverse the pollution and improve energy efficiency.

- Regulate the territorial concentrations of potentially polluting activities, taking into account the carrying capacity of industrial estates. Promote the expansion of industrial zones in areas farthest from areas of urban growth. In the case of Vilareal, we suggest expanding the industrial area west of the city centre.

Specific: Corrective measures in relation to the extraction, transportation, loading, unloading and storage of non-metallic mineral raw materials

These industrial activities are characterized by operations performed outdoors that produce diffuse dust emissions at ambient temperature. The measures proposed are as follows:

- Restrict, modify and/or alternate transport and delivery timetables of goods in the area.

- Irrigate raw materials into and out of the transport vehicles (e.g. construction materials, gravel, sand, and other raw clay materials).

- Clean vehicle wheels once the loading and unloading of raw materials is finished.

- In order to prevent emissions of particles into the atmosphere from transport losses, inspect big bags or any canvas that covers the materials.

- Irrigate outdoor clay storage, especially during the hours of solar radiation from 8 a.m. to 7 p.m., when the more intense winds are produced.

- Irrigate traffic areas in material storage areas out of doors. 
- Limit the height of outdoor stockpiles to control dust emissions.

- Store powdery raw materials (mainly clays) in indoor areas.

- Plant vegetation fences near sites of raw material transport with proper orientation to the direction of the prevailing wind in the locality. During the diurnal cycle of radiation from 7 a.m. to 6 p.m., the wind direction is generally from the south-east to the north-west.

- Encourage and promote any type of material transport in closed systems. (e.g. pneumatic conveying systems, especially those for use in manufacturing ceramic frits and glazes).

Specific: Corrective measures in manufacturing of tiles and frits, glazes and colours.

Corrective measures in the manufacture of frits, glazes, and colours are to be applied to the industrial processes characteristic of the area, which are carried out indoors and involve a process of treatment or processing of the original materials. The pollutants discharged into the atmosphere are generally issued by chimney at a high temperature. These emissions are produced during the preparation of raw materials (milling and spraying), moulding, drying, preparation and application of tile glaze and melting of frits and ceramic glazes. The proposed measures are as follows:

- Use pneumatic systems for the transport of raw materials in the various industrial processes.

- Install inlet valves at the sites of the different processes that may generate dust emissions.

- During the drying phase, brush the products to prevent resuspension and subsequent particle emissions by chimney. 
- Ensure good aspiration of the pieces in the kiln inlet in order to reduce particulate matter discharged by chimney.

- Purify gases at the chimney outlet.

- Encourage and promote the use of clean fuels and raw materials that are free of toxic compounds.

- Promote the implementation of environmental management systems to improve air quality through specific grants in this field.

\section{CONCLUSIONS}

The challenge to reduce air pollution and maintain a sustainable environment is immense. The European Parliament has established the need to reduce atmospheric pollution to minimise harmful effects on human health, with particular attention paid to sensitive populations, and reduce damage to the environment as a whole. This may be carried out by improving the monitoring and assessment of air quality and pollutant emissions and providing information to the public. With this in mind, the origin of pollutants in the study area and the possible methods of controlling them to improve the population's health were analysed in our investigation.

The study area of our paper is in the province of Castellón (Spain). This province is a strategic area in the frame work of European Union (EU) pollution control. Approximately $80 \%$ of European ceramic tiles and ceramic frit manufacturers are concentrated in two areas, forming the so-called "ceramics clusters"; ones in Modena (Italy) and the other in Castellón. In this kind of areas, there are a lot of air pollutants from this industry then it is difficult to fulfill de European limits of PM10 so it is necessary to control the air quality in them. 
Air quality assessment in terms of levels of atmospheric particles (PM10) was performed in this industrialised area according to European Union laws. The seasonal variation in the number of days in which the limit values for pollutants were exceeded have been evaluated and the sources of the contamination have been identified.

Air quality indexes of each pollutant have been established to serve as a tool to understand easily and clearly the quality of air in the study area. Thus, the public has been provided with a useful method of determining whether the concentration levels of pollutants are harmful to their health.

An Air Quality Plan is proposed in order to improve pollution control. General and specific corrective measures for the main emission sources have been provided.

The methodology carried out in this paper is a useful tool for developing future Air Quality Plans in other industrialised areas.

\section{ACKNOWLEDGES}

The present study was supported by Environment department of Vila-real and Almazora

city Councils. The authors wish to acknowledge "Serveis Centrals d'Intrumentació Científica" of the Jaume I University for their collaboration. 


\section{REFERENCE}

Alastuey A., Mantilla E.; Querol X., Rodríguez S., 2000. Study and evaluation of atmospheric pollution in Spain necessary measures arising from the EC Directive on PM10 and PM2.5 paricles in the Ceramic industry. Boletín de la Sociedad Española de Cerámica y Vidrio 39(1),135-148.

Bergametti G., Dutot A.L., Buat-Menard P., Losno P., Remoudaki E., 1989. Seasonal variability of de elemental composition of the atmospheric aerosol particles over the Nortwestern Mediterranean. Tellus. 41B, 353-361.

Bernardoni V., Vechhi R., Valli G., Piazzalunga A., Fermo P., 2011. PM10 sources apportioment in Milan (Italy) ussing time-resolved data. The Science of the Total Environment. 409:4788-4795.

Boix A., Company V., Jordán M.M., Sanfeliu T., 1995. Vectorial model to study the local breeze regimen and its relationship with $\mathrm{SO}_{2}$ and particle matter concentrations in the urban area of Castellón, Spain. The Science of the Total Environment 172:1-15.

Boix A., Jordán M.M., Querol X., Sanfeliu T., 2001. Characterization of total suspended particles around a power station in an urban coastal area in eastern Spain. Environmental Geology 40, 891-896. 
Chang S.C., Lee C.T., 2008. Evaluation of the temporal variations of air quality in Taipei City, Taiwan, from 1994 to 2003. Journal of Environmental Management. 86, $627-635$.

EN 12341:1999 Air quality: Determination of the PM10 fraction of the suspended particulate matter. Reference method and field test procedure to demonstrate reference equivalence of measurement methods.

European Council Directive 1999/30/EC of $22^{\text {th }}$ April 1999 relating to limit values for sulphur dioxide, nitrogen dioxide and oxides of nitrogen, particulate matter and lead in ambient air. Official Journal of the European Union L163, $26^{\text {th }}$ September, 1999. 41-60.

European Council Directive 2004/107/EC of $15^{\text {th }}$ December 2004 relating to arsenic, cadmium, mercury, nickel and polycyclic aromatic hydrocarbons in ambient air. Official Journal of the European Union L 23, $26^{\text {th }}$ January, 2005, 3-16.

European Council Directive 2008/50/EC of $21^{\text {st }}$ May 2008 on ambient air quality and cleaner air for Europe. Official Journal of the European Union L152, $11^{\text {th }}$ June, 2008, 144.

Foster, W.M., 1999. Deposition and clearance of inhaled particles. In: Air pollution and Health. Eds. Holgate S.T.; Samet J.M.; Koren H.S.; Maynard R.L. Ed. Academic Press. San Diego USA 295-324. 
Ghio A.J.; Samet J.M. (1999) "Metals and air pollution particles". En: Air pollution and health. Eds. Holgate S.T.; Samet J.M.; Koren H.S.; Maynard R.L. Ed. Academic Press. pp.634-651

Gómez, E.T., Sanfeliu, T., Jordán, M.M., Rius, J., 2005. Evolution, sources and distribution of mineral particles and amorphous phase of atmospheric aerosol in an industrial and Mediterranean coastal area. Water, air, and soil pollution 167, 311-330.

Jordán M.M, Álvarez C., Sanfeliu T., 2006. Spherical particles as tracers of atmospheric ceramic industry Environmental Geology 51, 447-453.

Jordán M.M., Martín-Martín J:D, Sanfeliu T, Gómez-Gras D, De la Fuente C., 2009. "Mineralogy and firing transformations of Permo-Triassic clays used in the manufacturing of ceramic tile bodies. Applied Clay Science 44, 173-177

Kantarci, M.D. and Karaöz, O., 2001. Air pollution effects on forests in Turkey. Fresenius Environmental Bulletin 10 (3), 323-328.

Kappos, A.D., Bruckman, P., Eikmann, T., Englert, N., Heinrich, U., Höppe, P., Koch, E., Kreyling, W.G., Rauchfuss, K., Rombout, P., Schulz-klemp, V., Thiel, W.R., Wichman, H.E., 2004. Health effects of particles in ambient air. International Journal of hygiene and environmental health 207,399-407.

Kelessis, A.G.,2001. Eleven years of primary air-pollutnat observation in the city of Thessalonki, Greece. Fresenius Environmental Bulletin 10 (7), 624-628. 
Kubilay, N. and Saydam, A.C., 1995. Trace elements in atmospheric particulate over the eastern Mediterranean; concentrations, sources and temporal variability. Atmospheric Environment 29, 1352-1310.

Le Tertre, A., Schwart, J., Touloumi, G., 2005. Empirical bayes and adjusted estimates approach to estimating the relation of mortality to exposure of PM10. Risk analysis 25(3), 711-718.

Li J., Guttikunda, S.K., Carmichael G.R., Streets D.G., Chang Y.S., Fung V., 2004. Quantifying the human health benefits of curbing air pollution in Shanghai. Journal of Environmental Management. 70, 49-62.

López J.M., Callén M.S., Murillo R., García T., Navarro M.V., De la Cruz M.T., Mastral M.V. 2005. Levels of selected metals in ambient air PM10 in an urban site of Zaragoza (Spain). Environmental Research 99:58-67.

Marcazzan G.M., Vaccaro S., Valli G., Vecchi R., 2001. Characterization of PM2.5 and PM10 particulatte matter in the ambient air of Milan (Italy). Atmospheric Environment $35,4639-4650$.

Martín M.; Plazas J.; Andrés M.D., Bezares J.C. Millán M.M., 1991. Comparative study of seasonal air pollutant behaviour in a Mediterranean coastal site: Castellón (Spain)" Atmospheric Environment 25A, 1523-1535. 
Mazzei F., D’Alessandro A., Lucarelli F., Nava S., Prati P., Valli G., Vecchi R., 2008. Characterization of particulate matter sources in an urban environment. The Science of the Total Environment 401:81-89.

McMichael, A.J., Woodruff, R.E., .Hales, S., 2006. Climate change and human health; present and future risk. Lancet 367, 859-869.

Millán M.M.; Artiñano B.; Alonso L.; Navazo M.; Castro M., 2001, The effect of mesoscale flows on regional and long-range atmospheric transport in the western Mediterranean area" Atmospheric Environment 25A(5/6), 946-963

Minguillón M.C., Querol X., Alastuey A., Monfort E., Mantilla E., Sanz M.J., Sanz F., Roig A., Renal A., Felis C., Miró J.V., Artiñano B., 2007. PM10 speciation and determination of air quality target levels. A case study in a highly industrialized area of Spain" Science of the total environment 372, 382-396.

Miguillón M.C., Monfort E., Querol X., Alastuey A., Celades I., Miró J.B., 2009. Effect of ceramic industrial particulate emisión control on key components of ambient PM10. Journal of Environmental Management 90, 2558-2567.

Monn Ch.; Braenli O.; Schaeppi G.; Schindler Ch,; Ackermann-Liebrich U.; Leuenberger $\mathrm{Ph}$. and Sapaldian team, 1995. Particulate matter $<10 \mu \mathrm{m}$ (PM10) and total suspended particulate (TPS) in urban rural and alpine air in Switzerland. Atmospheric Environment 29, 2565-2573. 
Neuberger, M., Schimek, M.G., Horak, F. Jr., Moshammer, H., Kundi, M., Frischer, T., Gomiscek, B., Puxbaum, H., Hauch,,H., 2004. Acute effects of particulate matter on respiratory diseases, symptoms and functions: epidemiological results of the Australian Project on health effects of particulate matter (AUPHEP). Atmospheric Environment $38,3971-3981$

Pacyna J.M.; Semb A.; Hanssen J.E. 1984. Emission and long-range transport of trace elements in Europe. Tellus 36B:163-178.

Pacyna J.M. 1998. Sources inventories for atmospheric trace metals. In: Atmospheric particles. IUPAC Series on analytical and physical chemistry of environmental systems. Eds. Harrison R.M.; Van Grieken R:E. Ed. J. Wiley \& sons Vol.5:385-424.

Pallarés S., Vicente A.B., Jordán M.M., Sanfeliu T. 2007 Study of the Levels of Concentration of $\mathrm{As}, \mathrm{Cd}$ and $\mathrm{Ni}$ in a Ceramic Cluster. Water, Air and Soli Pollution 180:51-64.

Parekh P.P., Khwaja H.A., Khan A.R., Naqvi R.R. 2002. Lead content of petrol and diesel and its assessment in an urban environment. Environmental Monitoring and Assessment 74:255-262.

Pérez, C., Nickovic, S., Baldasano, J.M., Sicard, M., Rocadenbosch, R., 2006. A long Saharan dust event over the western Mediterranean: Lidar sun photometer observations, and regional dust modeling. Journal of Geophysical Research Vol. 111, D15214 doi: 10.1029/2055JD006579. 
Pogosyan K.H.P., 1965. The air envelope of the earth. Published by The Israel program for scientific translations. Jerusalem

Querol, X., Alastuey, A., López-Soler, A., Plana, F., 2000. Levels and chemistry of atmospheric particulates induced by spill of heavy metal mining wastes in the Doñana area Southwest, Spain. Atmospheric Environment 34, 239-253.

Querol X.; Alastuey A.; Rosa J.; Sánchez-De-La-Campa A.; Plana F.; Ruir C.R., 2002. Source apportiment analysis of atmospheric particles in an industrialised urban site in Southwestern Spain. Atmospheric Environment 36, 3113-3125.

Querol X., Alastuey A., Moreno T, Viana M.M., Castillo S., Pey J.,Rodríguez S, Artiñano B, Salvador P., Sánchez M, Garcia Dos Santos S., M.D. Herce Garraletac, R. Fernandez-Patierc, S. Moreno-Graud, L. Negrald, M.C. Minguillón, E. Monfort, M.J. Sanz, R. Palomo-Marín, E. Pinilla-Gil, E. Cuevas, J. de la Rosa, A. Sáchez de la Campa. 2008. Spatial and temporal variations in airborne particulate matter (PM10 and PM2.5) across Spain 1999-2005. Atmospheric Environment 42,3964-3979.

Rodríguez, S., Querol, X., Alastuey, A., Kallos, G., Kakaliagaou, O. 2001. Saharan dust contribution to PM10 and TPS levels in southern and eastern Spain. Atmospheric Environment 32, 2433-2447. 
Rodríguez, S., Querol, X., Alastuey, Mantilla E., 2002. Origin of high summer PM10 and PST concentrations at rural sites in Eastern Spain. Atmospheric Environment 36, $3101-3112$

Sanfeliu T., Jordán M.M., Gómez E.T., Álvarez C., Montero M.A., 2002. Distribution of the atmospheric emissions of Spanish ceramics industries. Environmental Geology 41, 601-607.

Sanfeliu T., Jordán M.M., 2009. Geological and environmental management of ceramic clay quarries: a review. Environmental Geology 57, 1613-1618.

Shah M.H., Jaffar M., Khalique A., Tariq S.R., Manzoor S. 2006. Spatial variations in selected metal contents and particle size distribution in an urban and rural atmosphere of Islamabad, Pakistan. Journal of Environmental Management 78, 128-137.

Sivakumar, M.V.K., 2007. Interactions between climate and desertification. Agricultural and forest Meteorology 42(2-4), 143-155.

Vicente A.B., Jordan M.M., Pallarés S., Sanfeliu T., 2007. PM10 and Pb evolution in an industrial area of the Mediterranean basin. Environmental Geology 51, 1413-1424.

Vicente A.B., Sanfeliu T., Jordan M.M., 2011. Comparison between industrial-urban and rural particle stations in a ceramic cluster (NE, Spain). Water, Air and Soil Pollution 215, 83-96. 
Wallace J., Corr D., Kanaroglou P., 2010. Topographic and spatial impacts of temperature inversions on air quality using mobile air pollution surveys. Science of The Total Environment 408, 5086-5096.

Wilson, J.G., Kingham, S., Earce J., Sturman, A.P., 2005. A review of intraurban variation in particulate air pollution: Implications for epidemiological research. Atmospheric Environment 39, 6444-6462.

Zoras S., Triantafyllou A.G., Deligiorgi D., 2006. Atmospheric stability and PM10 concentrations at far distance from levated point sources in complex terrain: Worst-case episode study. Journal of Environmental Management 80, 295-302. 
Table 1 Air quality comparison of PM10 in the five years of study.

\begin{tabular}{|c|c|c|c|c|c|c|}
\hline $\begin{array}{l}\text { Averaging } \\
\text { period }\end{array}$ & $\begin{array}{c}\text { Limit value } \\
\text { PM10 }\left(\mu \mathrm{g} / \mathrm{m}^{3}\right)\end{array}$ & 2001 & 2002 & 2003 & 2004 & 2005 \\
\hline $\begin{array}{l}\text { Daily limit } \\
\text { value } \\
24 \text { hours }\end{array}$ & $\begin{array}{l}50 \text { not to be } \\
\text { exceeded more } \\
\text { than } 35 \text { times a } \\
\text { calendar year }\end{array}$ & $\begin{array}{c}87 \\
\text { exceedances }\end{array}$ & $\begin{array}{c}70 \\
\text { exceedances }\end{array}$ & $\begin{array}{c}70 \\
\text { exceedances }\end{array}$ & $\begin{array}{c}77 \\
\text { exceedances }\end{array}$ & $\begin{array}{c}94 \\
\text { exceedances }\end{array}$ \\
\hline $\begin{array}{l}\text { Annual } \\
\text { limit value } \\
\text { Calendar } \\
\text { year } \\
\end{array}$ & 40,0 & 52,0 & 51,0 & 47,2 & 46,3 & 52,3 \\
\hline
\end{tabular}


$\underline{\text { Table } 2}$ Percentages of daily limit value exceedances

\begin{tabular}{cccccc}
$\begin{array}{c}\text { Exceedance percentage } \\
\text { Limit PM10 } \\
\mathbf{n = 3 6 5} \text { days }\end{array}$ & $\begin{array}{c}\mathbf{2 0 0 1} \\
\mathbf{n = 1 8 4}\end{array}$ & $\begin{array}{c}\mathbf{2 0 0 2} \\
\mathbf{n}=\mathbf{1 5 0}\end{array}$ & $\begin{array}{c}\mathbf{2 0 0 3} \\
\mathbf{n}=\mathbf{1 7 8}\end{array}$ & $\begin{array}{c}\mathbf{2 0 0 4} \\
\mathbf{n}=\mathbf{1 9 4}\end{array}$ & $\begin{array}{c}\mathbf{2 0 0 5} \\
\mathbf{n}=\mathbf{1 8 1}\end{array}$ \\
\hline $9,6 \%$ & $47,3 \%$ & $46,7 \%$ & $39,9 \%$ & $39,7 \%$ & $51,9 \%$ \\
\hline
\end{tabular}


Table 3 Intrusion days of particulate matter on the study area.

\begin{tabular}{llllll}
\hline \multicolumn{1}{c}{ Mes } & \multicolumn{1}{c}{$\mathbf{2 0 0 1}$} & \multicolumn{1}{c}{$\mathbf{2 0 0 2}$} & \multicolumn{1}{c}{$\mathbf{2 0 0 3}$} & \multicolumn{1}{c}{$\mathbf{2 0 0 4}$} & \multicolumn{1}{c}{$\mathbf{2 0 0 5}$} \\
\hline January & $4,8,9,11,22,24$ & $11-13,30-31$ & - & 8 & - \\
February & 23,24 & $2-3,11-13$ & $24-26$ & $8-9 ; 20-21$ & 8 \\
March & $6,7,8,16$ & $12-13,21-23$ & $12-15,18-19$ & $6,9-10,16-20$, & $13-25$ \\
& & & $22-27$ & $28-29$ & \\
April & $7,20,22$ & $7-9$ & $7-9,14-19$ & 15,29 & $8,28-30$ \\
May & $7,9,10,20,21$ & $15-17,29-31$ & $3-10,30-31$ & $3-4,11-12$, & $1-5,21,30-31$ \\
& & & & $20-24$ & \\
June & $24-26$ & $1-4,15-27$ & $1-2,7-18$, & $7-13,27-28$ & $1-6,12,26-28$ \\
& & & $26-26$ & & \\
July & $21-25,29-31$ & $7-8,19-23$, & $7-15,17-24$, & $6-7,17-19$, & $17-18,27-28$ \\
& & $27-29$ & $30-31$ & $21-25,28-29$ & \\
August & $1,2,11-14,26$ & $4-5,14-15$, & $2-3,13,16-17$, & $2-3,7-9$, & $9-10,17-18$ \\
& & $19-20$ & $21-24$ & $22-28$ & \\
September & - & $2-4$ & $3-5$ & $1-14$ & $4-5$ \\
October & 5,12 & $7-8,20-21$ & - & $4-9,23-25$ & $16,29-31$ \\
November & - & - & $9,17-23$ & 30 & $3-4,8$ \\
December & - & - & $6-7$ & 4,5 & - \\
\hline
\end{tabular}

Source: Generalitat Valenciana www.gva.es 
Table 4 Daily Quality Index Criterion for PM10

\begin{tabular}{llll}
$\begin{array}{c}\text { PM10 Range } \\
\boldsymbol{\mu g} / \mathbf{m}^{3}\end{array}$ & Quality & Pollution & Colour \\
\hline $0-25$ & Excellent & Low \\
$25-50$ & Good & Normal \\
$50-75$ & Poor & High \\
$>75$ & Bad & Very high & \\
\hline
\end{tabular}


Table 5 Comparison of air quality as $\mathrm{As}, \mathrm{Cd}, \mathrm{Ni}$ and $\mathrm{Pb}$ in PM10 during the study.

\begin{tabular}{lcccccc}
\hline Pollutant & $\begin{array}{c}\text { Target value } \\
\left(\mathbf{n g} / \mathbf{m}^{\mathbf{3}}\right)\end{array}$ & $\mathbf{2 0 0 1}$ & $\mathbf{2 0 0 2}$ & $\mathbf{2 0 0 3}$ & $\mathbf{2 0 0 4}$ & $\mathbf{2 0 0 5}$ \\
\hline Lead & 500 & 300 & 300 & 200 & 100 & 100 \\
Arsenic & 6,0 & 16,0 & 15,0 & 9,8 & 4,0 & 2,5 \\
Cadmium & 5,0 & 1,8 & 2,4 & 2,2 & 2,0 & 0,4 \\
Nickel & 20,0 & 6,1 & 5,6 & 3,9 & 4,9 & 5,3 \\
\hline
\end{tabular}

(1) For the total content in the PM10 fraction averaged over a calendar year 
Tabla 6 Quality Index Criterion for $\mathrm{As}, \mathrm{Cd}, \mathrm{Ni}$ y $\mathrm{Pb}$ in PM10

\begin{tabular}{cccclll}
\hline $\begin{array}{c}\mathbf{A s} \\
\mathbf{n g} / \mathbf{m}^{\mathbf{3}}\end{array}$ & $\begin{array}{c}\mathbf{C d} \\
\mathbf{n g} / \mathbf{m}^{\mathbf{3}}\end{array}$ & $\begin{array}{c}\mathbf{N i} \\
\mathbf{n g} / \mathbf{m}^{\mathbf{3}}\end{array}$ & $\begin{array}{c}\mathbf{P b} \\
\boldsymbol{\mu} \mathbf{g} / \mathbf{m}^{\mathbf{3}}\end{array}$ & Quality & Pollution & Colour \\
\hline $0-2$ & $0-1$ & $0-5$ & $0,0-0,1$ & Excelente & Muy Baja & \\
$2-6$ & $1-5$ & $5-20$ & $0,1-0,5$ & Buena & Baja & \\
$6-10$ & $5-10$ & $20-35$ & $0,5-0,9$ & Mejorable & Elevada & \\
$>10$ & $>10$ & $>35$ & $>0,9$ & Deficiente & Muy elevada & \\
\hline
\end{tabular}




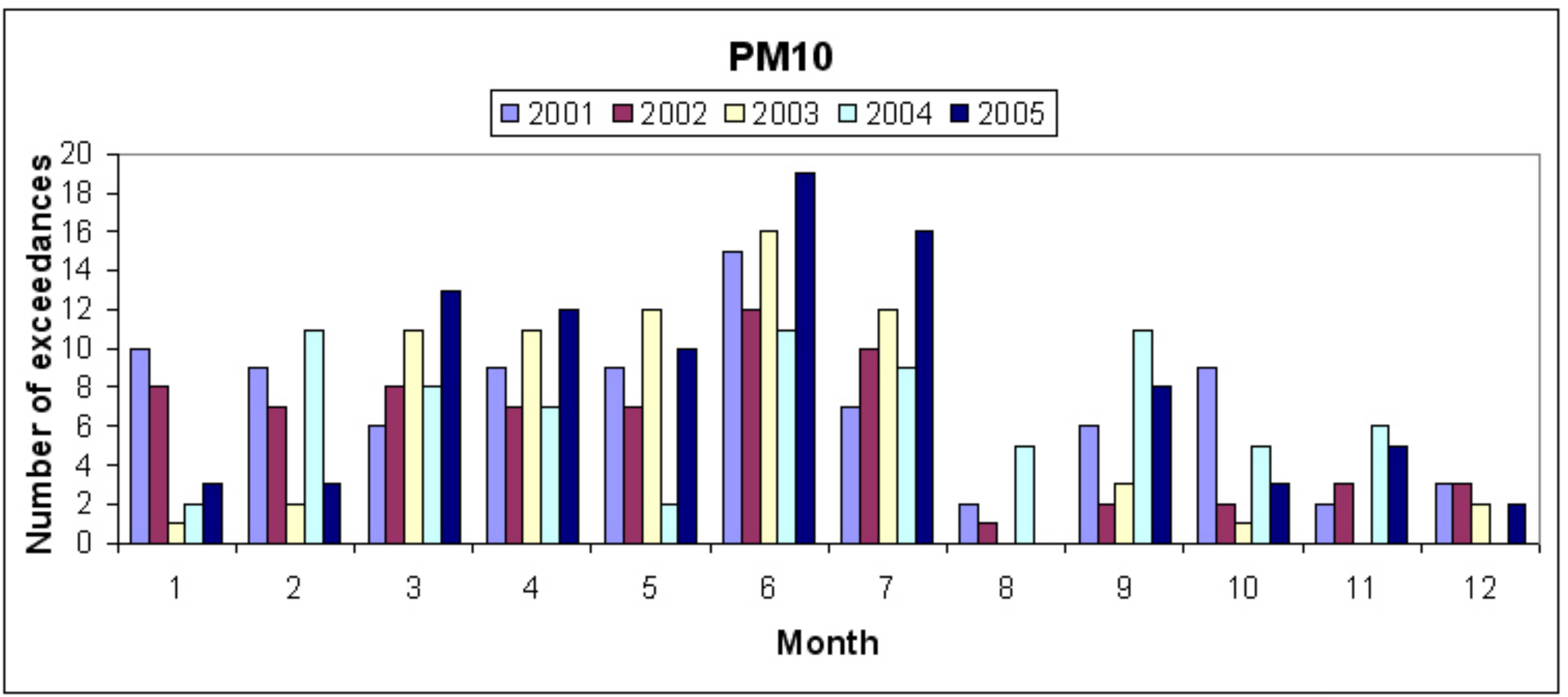

Figure 2 Number of exceedances of the guideline value for PM10 $\left(50 \mu \mathrm{g} / \mathrm{m}^{3}\right)$ per month 


\section{PM10}

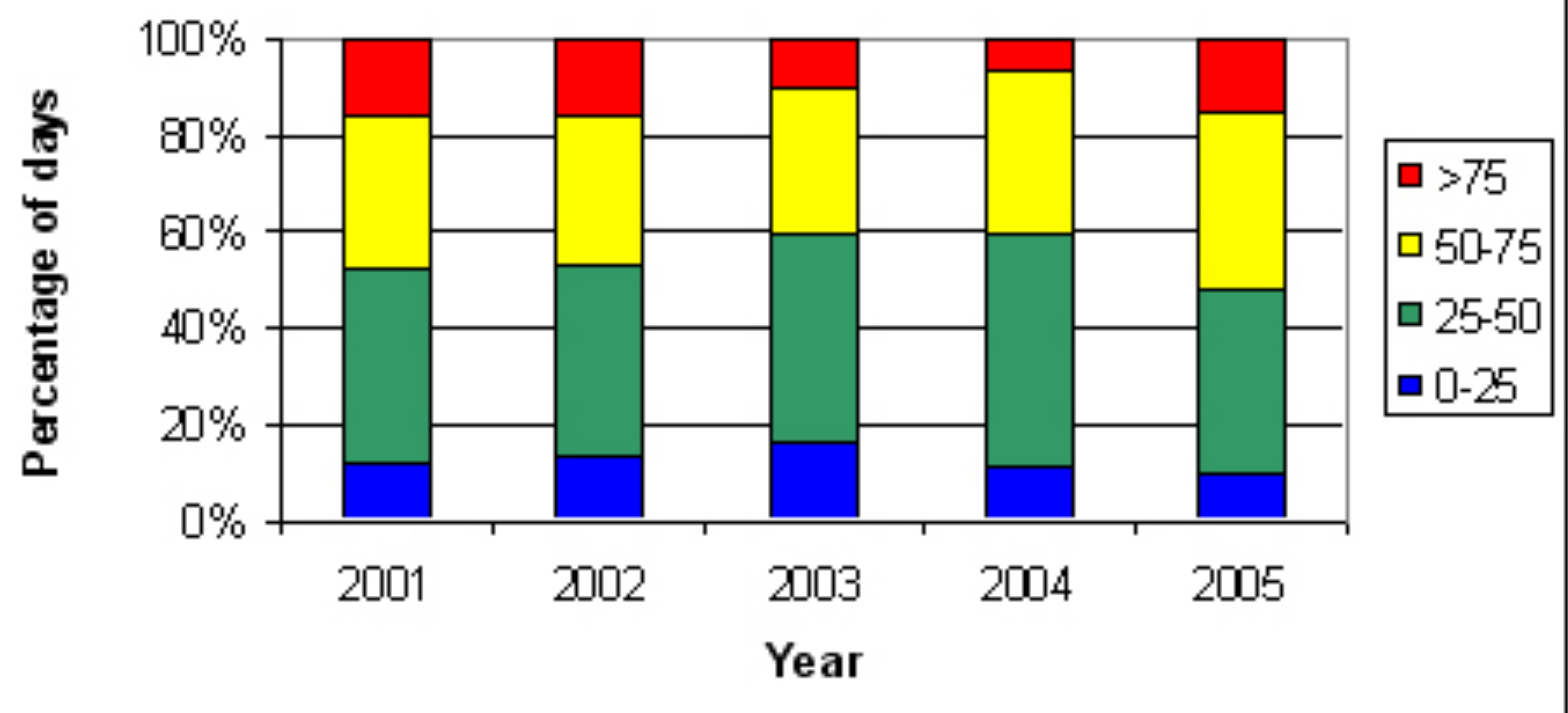

Figure 3 Percentage of days in each range of PM10 $\left(\mu \mathrm{g} / \mathrm{m}^{3}\right)$ 


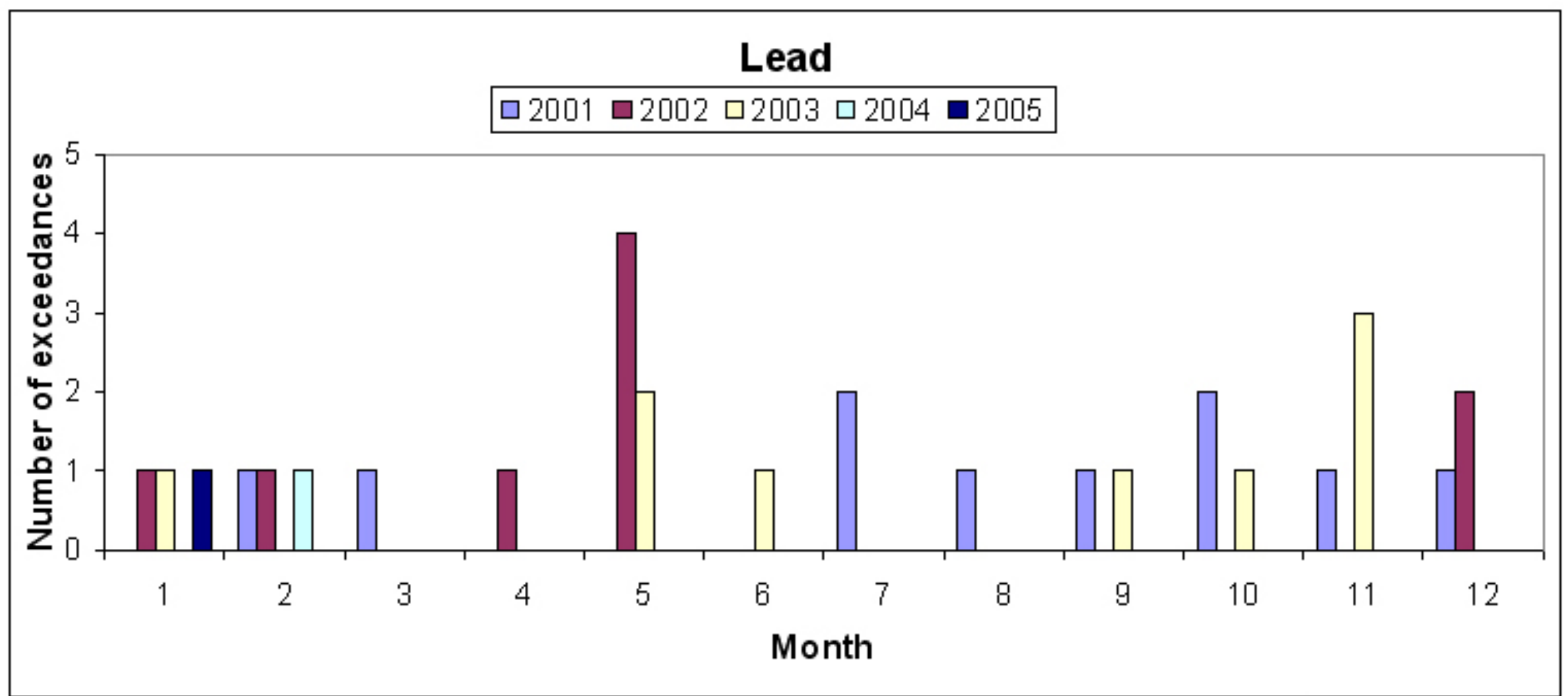

Figure 4 Number of excee dances of the guideline value for $\mathrm{Pb}\left(500 \mathrm{ng} / \mathrm{m}^{3}\right)$ per month 


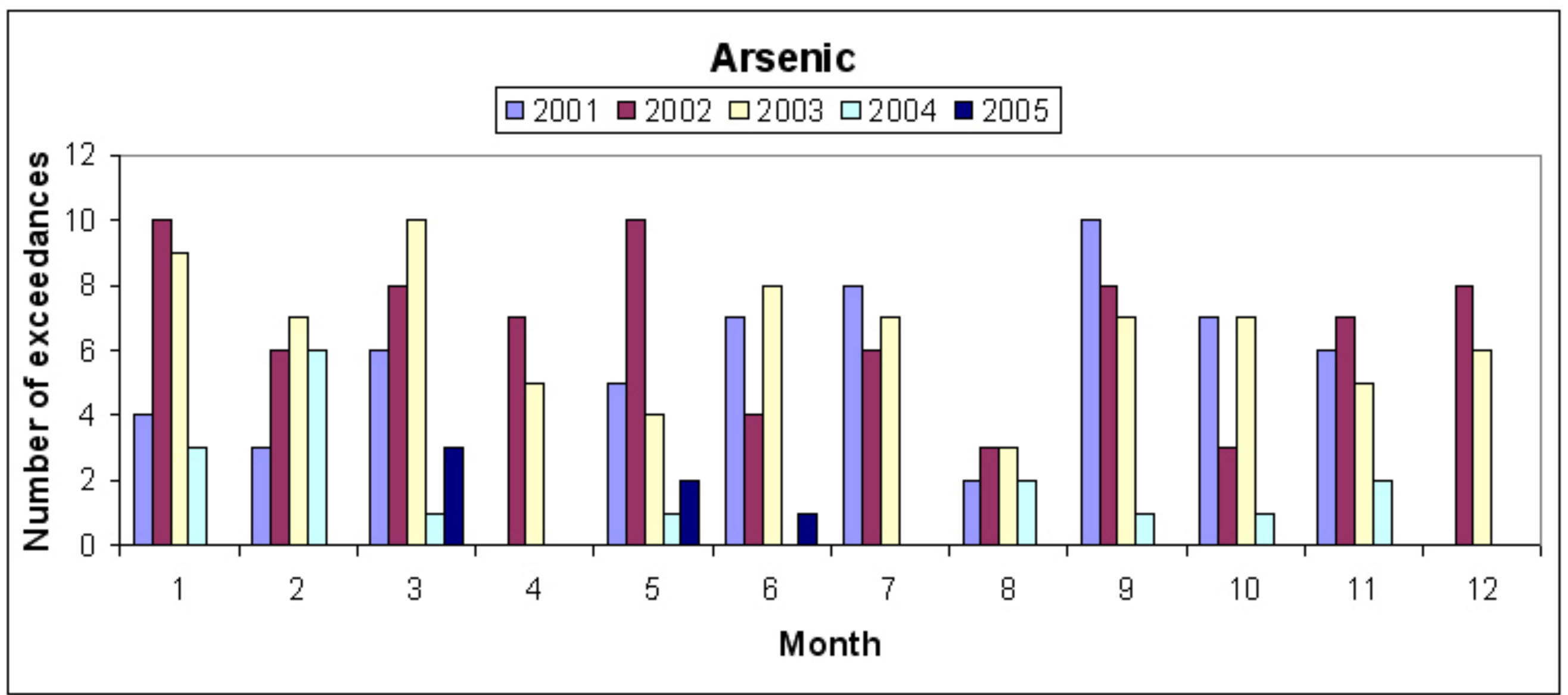

Figure 5 Number of exceedances of the guideline value for As $\left(6 \mathrm{ng} / \mathrm{m}^{3}\right)$ per month 


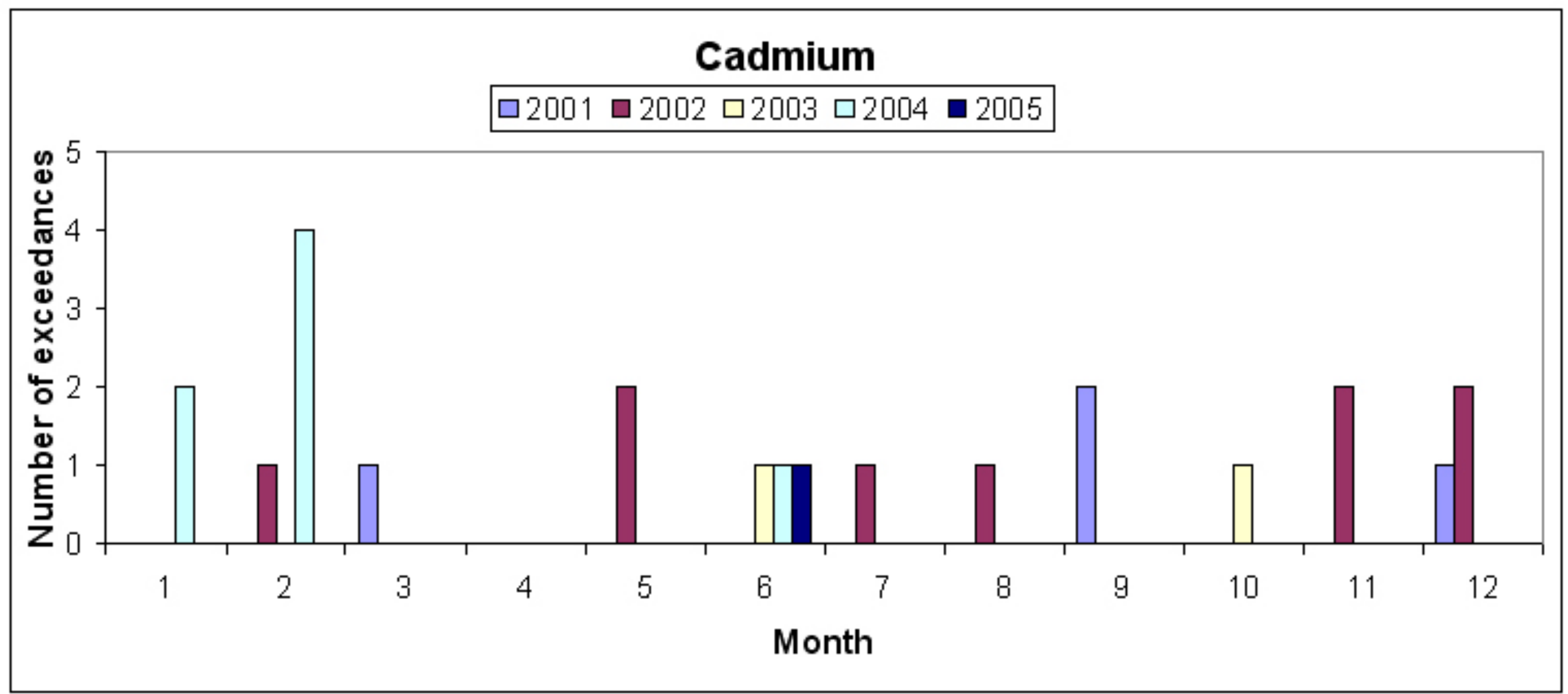

Figure 6 Number of exceedances of the guideline value for $\mathrm{Cd}\left(5 \mathrm{ng} / \mathrm{m}^{3}\right)$ per month 


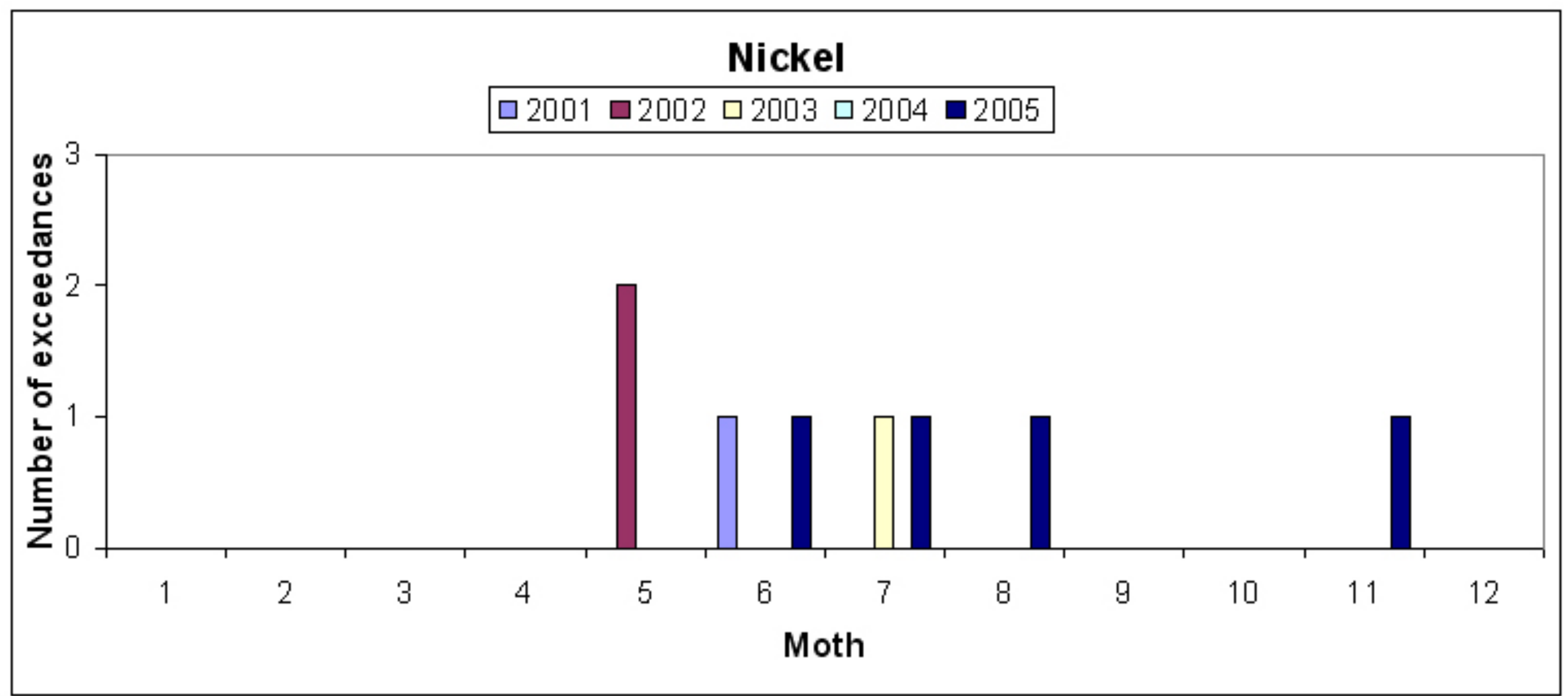

Figure 7 Number of exceedances of the guideline value for $\mathrm{Ni}\left(20 \mathrm{ng} / \mathrm{m}^{3}\right)$ per month 


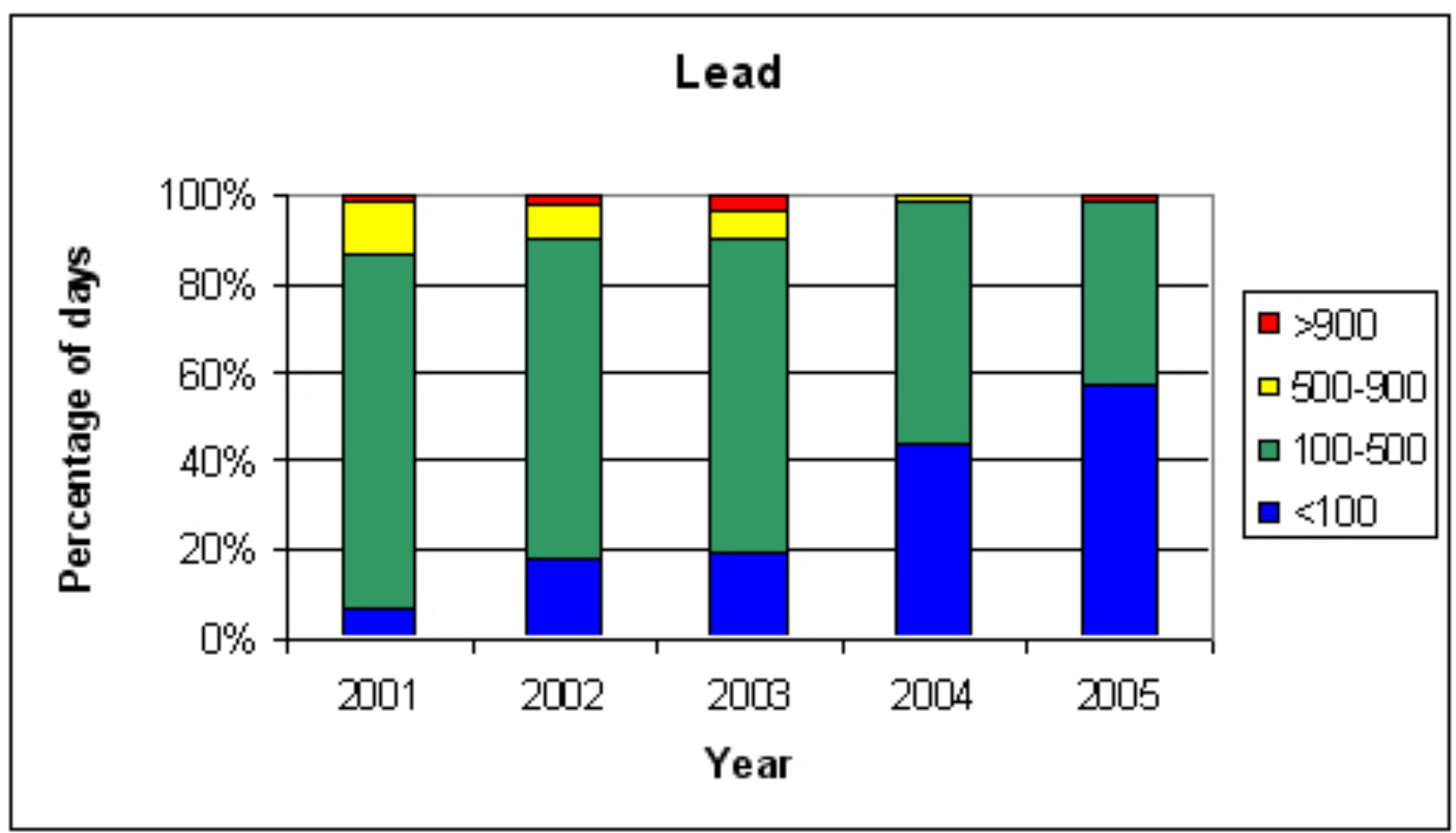

Figure 8 Percentage of days in each range of $\mathrm{Pb}\left(\mathrm{ng} / \mathrm{m}^{3}\right)$ 


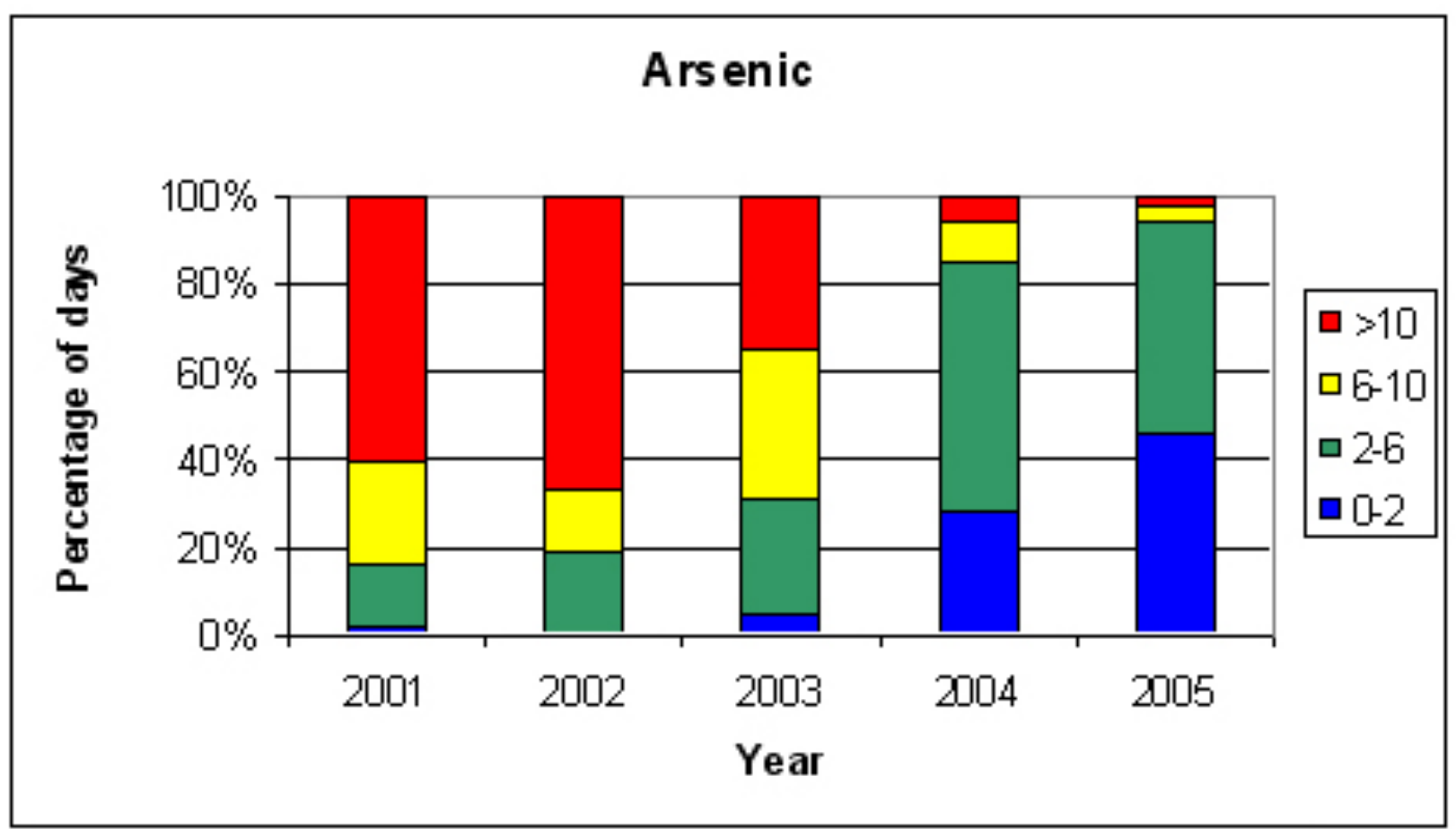

Figure 9 Percentage of days in each range of $\mathrm{As}\left(\mathrm{ng} / \mathrm{m}^{3}\right)$ 
Cadmium

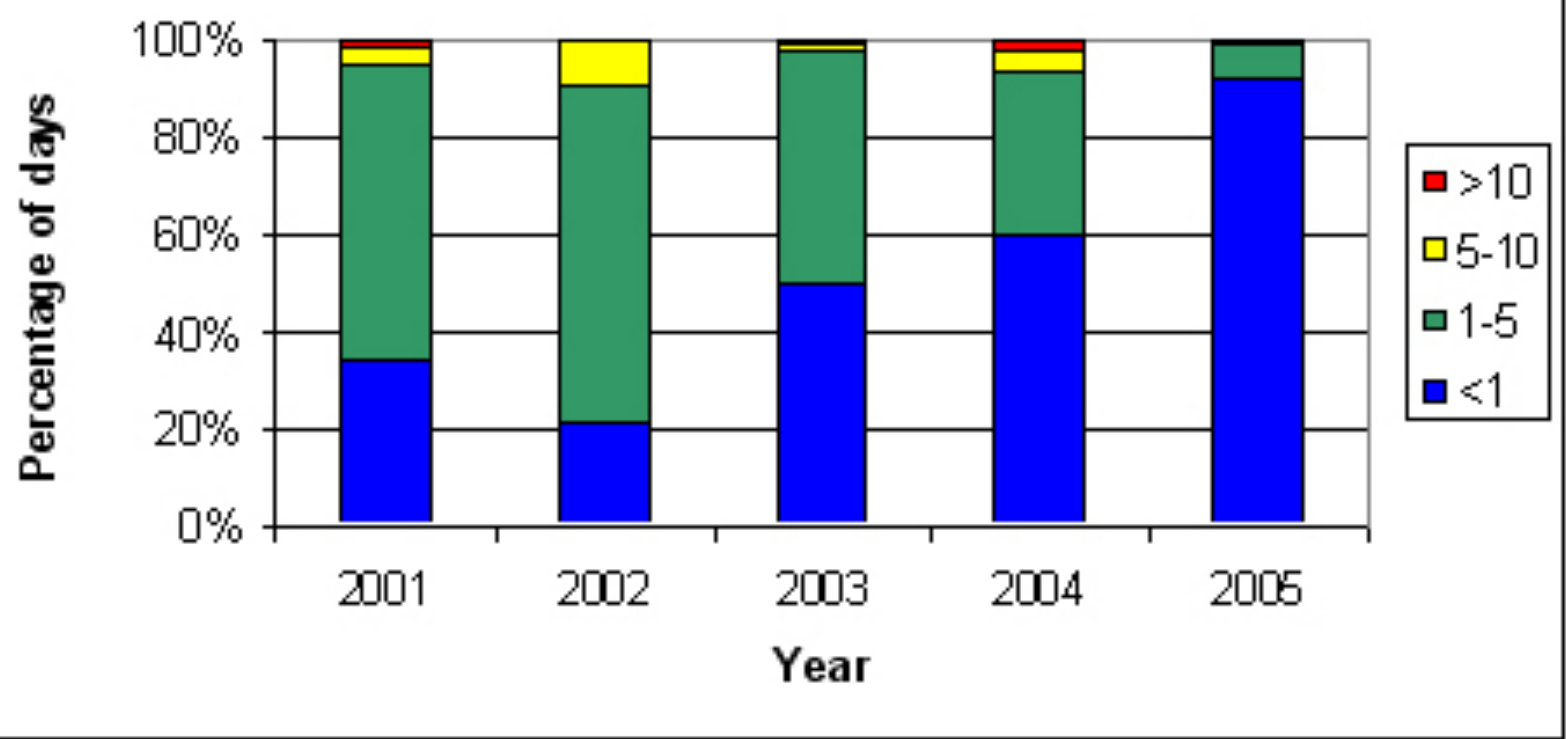

Figure 10 Percentage of days in each range of $\mathrm{Cd}\left(\mathrm{ng} / \mathrm{m}^{3}\right)$ 


\section{Nickel}

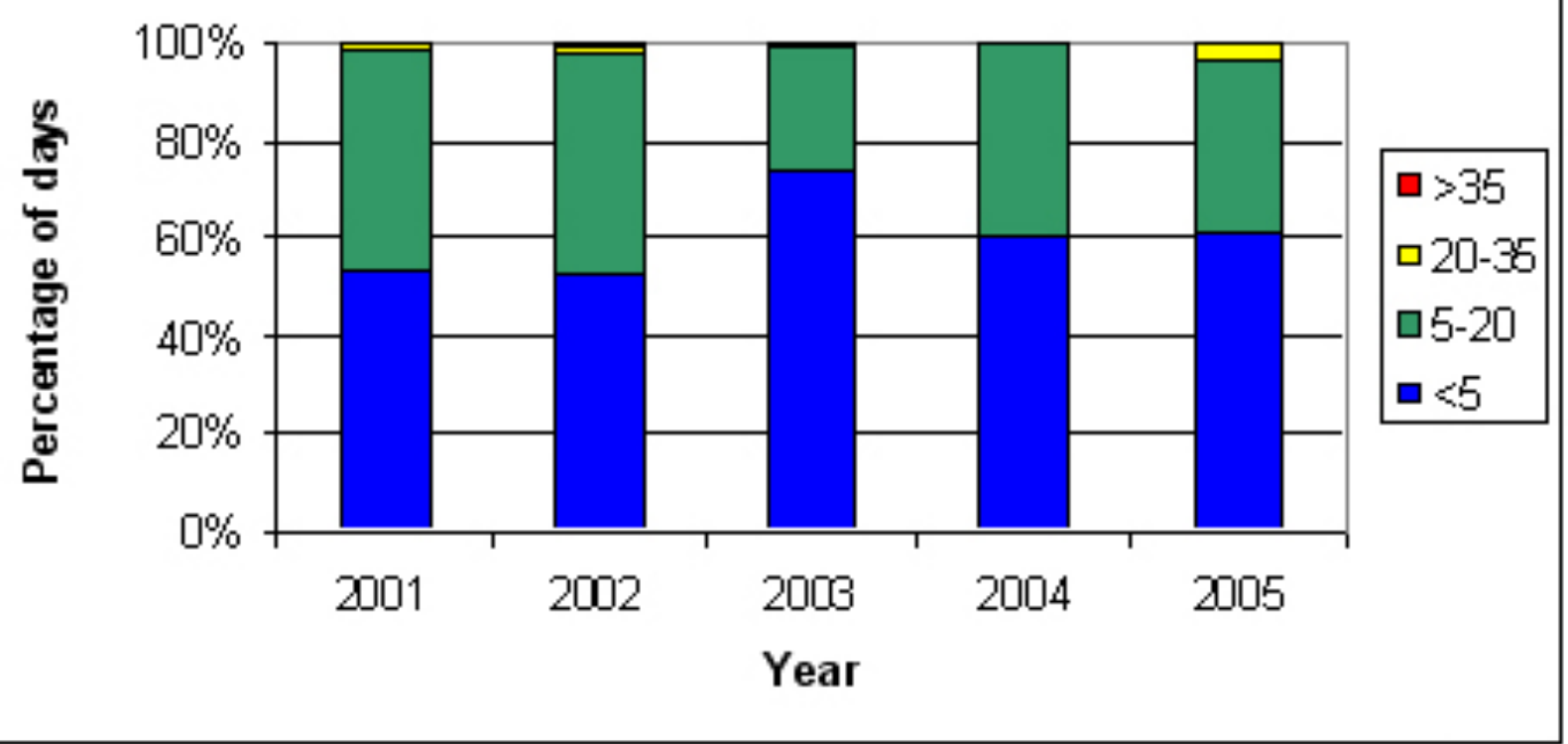

Figure 11 Percentage of days in each range of $\mathrm{Ni}\left(\mathrm{ng} / \mathrm{m}^{3}\right)$ 